\title{
STRUCTURAL BREAKS AND CROSS-CONTINENTAL REAL ESTATE SECURITIES DIVERSIFICATION: EVIDENCE FROM SPANNING TESTS
}

\author{
MING-LONG LEE \\ National Yunlin University of Science and Technology, Taiwan
}

\author{
MING-TE LEE \\ Yuan Ze University, Taiwan
}

and

\author{
KEVIN CHIANG \\ University of Vermont
}

\begin{abstract}
This study uses mean-variance spanning tests to examine the role of Asian and European real estate securities in real estate-only portfolios from a U.S. investor's perspective. The results show that including overseas real estate securities helps enhance the meanvariance efficient frontier only when the portfolio does not include direct real estate assets. Furthermore, the diversification benefit of investing in Asian real estate stocks appears only in the vintage REIT era; it disappears in the new REIT era and after the Asian financial crisis. Moreover, after stripped out the equity market influence from international real estate stocks, the results indicate that trading noise in the equity markets could cause real estate stocks to deviate from their real estate fundamentals and thus reduce the diversification benefits to U.S. real estate investors.
\end{abstract}

Keywords: Structural breaks, spanning test, real estate, property, portfolio

\section{INTRODUCTION}

Institutional investors have increasingly accepted real estate as a distinct asset class that deserves a permanent strategic allocation in a multi-asset class portfolio. Nevertheless, only a small subset of U.S. investors have international real estate exposure within their overall allocation (Bigman and Chiu, 2005). In light of the rapid evolution of the global real estate market and the ever-increasing globalization of financial markets, Bigman and Chiu (2005) argue that investors should implement a strategic allocation to global real 
estate to achieve higher risk-adjusted returns. Furthermore, the authors believe that this strategic allocation can be implemented through real estate securities.

This belief is shared by many other researchers who favor using international real estate securities to overcome the difficulties of buying direct real estate offshore (Worzala and Sirmans, 2003; Wilson and Zurbruegg, 2003). The results in Gilberto (1990), Asabere, Kleiman and McGowan (1991), Addae-Dappah and Kion (1996), Eichholtz (1997), Pierzak (2001), Bigman (2002), and Liow and Sim (2006) support the notion that holding international real estate securities is a beneficial strategy to achieve risk reduction in the short-run under the mean-variance framework. However, not all research supports this belief. In fact, Mull and Soenen (1997) and Stevenson (2000) present evidence casting doubt on the diversification benefit from investing in international real estate stocks. Nevertheless, most of these previous studies stop short of presenting a formal statistical test on whether the inclusion of international real estate securities enhances the efficient frontier of a real estate portfolio. One exception is Stevenson (2003). Employing meanvariance spanning tests for real estate securities in 12 nations and supporting the belief, he shows that significant overseas diversification opportunities are available to U.S. REIT investors in most countries over the period 1980-2002 (Stevenson, 2003).

In another strand of the international real estate literature, Eichholtz (1996), Liu and Mei (1996), and Wilson and Okunev (1996) show that international real estate markets are not integrated. In line with these authors and overall, but not entirely and individually consistent with his spanning test results, Stevenson (2003) finds no evidence of cointegration of U.S. REITs with the real estate securities in the majority of studied countries. The author's co-integration test results imply risk-reduction benefits through international diversification in the long-run. However, the author's results are not without challenges. The reason for this is that co-integration test results can be sensitive to the existence of structural breaks. Wilson and Zurbruegg's (2002) co-integration analysis shows that once possible structural breaks are taken into account, international real estate markets (Australia, Japan, UK and USA) have been interrelated since the early 1990s.

Given the results in Wilson and Zurbruegg (2002), it is interesting to investigate the influence of possible structural breaks on the diversification benefits of international real estate securities in the short-run under the mean-variance framework. It is likely that the diversification opportunities in the short run differ from in the long run. In fact, around half of the nations in Stevenson (2003) study provide significant short-run diversification opportunities to U.S. REIT investors, but no long-run opportunities or vice versa.

The purpose of this study is to implement spanning tests on cross-continental diversification and seek further evidence regarding whether international real estate securities improve investment opportunity sets of U.S. real estate investors in the short run under the mean-variance framework before and after structural breaks. 
Studying cross-continental diversification is consistent with the top-down approach executed in portfolio management, particularly when constructing portfolios of public traded real estate securities (Hamelink and Hoesli, 2004). Eichholtz, Mahieu and Schotman (1993) suggest that cross-continental investment is necessary to achieve optimal international real estate stocks diversification. In addition, Torto (2002) advises that, for North America investors, most international real estate diversification benefits comes from cross-continental investing, specifically in Asia and Europe. In particular, Pierzak (2001) and Bigman (2002) indicate that Asian real estate securities appear to provide largest potential diversification benefits to U.S. investors. Therefore, this study focuses on the potential diversification opportunities of holding Asian and European real estate securities.

It is widely known that the growth of U.S. REIT markets and increasing participation by institutional investors resulted in a structural change in the early 1990s (Glascock, Lu and So, 2000). Several studies also find that institutional participation changes REIT return behavior (Crain, Cudd and Brown, 2000; Lee and Lee, 2003; Chan, Leung and Wang, 2005). In addition, Liow and Sim (2006) suggest that returns of U.S. REITs and Asian real estate securities have became more interdependent after the 1997-1998 Asian financial crisis. To account for the potential impact of these events, our tests are implemented for the whole sample period as well as for various sub-periods.

This study considers a broader set of domestic benchmark assets, including securitized and/or unsecurtitized real estate. The correlation analyses in Pierzak (2001) and Bigman (2002), as well as the statistical tests in Stevenson (2000, 2003), do not include unsecuritized real estate. Torto (2002) analyzes only the correlations of physical real estate returns. We believe that broadening the domestic asset set is important because institutional investors may have both securitized and unsecuritized real estate in their portfolios.

Our spanning test results show that including Asian and European real estate securities help enhance the mean-variance efficient frontier of U.S. investors when the benchmark assets do not include unsecuritized real estate. However, after stripping out the stock market influences, the test results confirm that cross-continental real estate investing provides significant diversification benefits, even when US investors already hold physical real estate in their domestic portfolios. Further analyses indicate that the diversification benefits after the structural breaks come primarily from European rather than Asian real estate investment.

\section{MEAN-VARIANCE SPANNING TESTS}

Academicians and practitioners are often interested in finding out whether the addition of new asset classes (test assets) can improve the efficient frontier of the existing set of asset classes (benchmark assets). This question was first formally addressed by Huberman and 
Kandel (1987). Their null hypothesis is that the efficient frontier of a set of $K$ benchmark assets is the same as the efficient frontier of the $K$ benchmark assets plus a set of $N$ additional test assets, where $N$ has the value of one or more. If the null hypothesis is rejected, the evidence supports the notion that the test assets expand the mean-variance efficient frontier and provide diversification benefits.

A complete survey of mean-variance spanning tests can be found in Kan and Zhou (2001). This section briefly describes these statistical tests. The $K$-vector returns on the $K$ benchmark assets are denoted as $R_{1 t} . R_{2 t}$ is an $N$-vector of the returns on the $N$ test assets. $R_{t} \equiv\left[\mathrm{R}^{\prime}{ }_{1 t} \mathrm{R}^{\prime}{ }_{2 t}\right]^{\prime} . \quad E\left[R_{t}\right] \equiv \mu . \operatorname{Var}\left[R_{t}\right] \equiv V$. Ordinary least squares are used to estimate the following specification:

$R_{2 t}=\alpha+\beta R_{1 t}+\varepsilon_{t}, t=1,2, \ldots, T(R=X B+E$ in matrix form $)$,

where $\varepsilon_{t}$ is independently and identically distributed as a multivariate normal with mean zero and variance $\Sigma$. Define $\delta \equiv 1_{N}-\beta 1_{K}$, where $1_{N}$ is an $N$-vector of ones. The null hypothesis is that:

$H_{0}: \alpha=0_{N}, \delta=0_{N}$.

The logic of the test is that, if the tangency portfolio and the global minimum-variance portfolio have zero weights in the test assets, the two-fund separation theorem guarantees that every portfolio on the efficient frontier of the $N+K$ assets will have zero weights in the test assets.

Define $\Theta=\left[\begin{array}{ll}\alpha & \delta\end{array}\right]$ '. Denote $\lambda_{1}$ and $\lambda_{2}$ as the two eigenvalues of $\hat{H} \hat{G}^{-1}$ :

$\hat{H}=\hat{\Theta} \hat{\Sigma}^{-1} \hat{\Theta}$,

$\hat{G}=T A(X, X)^{-1} A^{\prime}$

$A=\left[\begin{array}{cc}1 & 0^{\prime}{ }_{K} \\ 0 & -1^{\prime}{ }_{K}\end{array}\right]$

This leads to the first test, the likelihood ratio test:

$L R=T \sum_{i=1}^{2} \ln \left(1+\lambda_{i}\right)$.

The second test is a Wald test:

$W=T\left(\lambda_{1}+\lambda_{2}\right)$.

The third test is a Lagrange multiplier test: 
$L M=T \sum_{i=1}^{2} \frac{\lambda_{i}}{1+\lambda_{i}}$

$L R, W$, and $L M$ all have an asymptotic $x_{2 N}^{2}$ distribution. The fourth test is an $F$ test:

$\left(\frac{1}{U}-1\right)\left(\frac{T-K-1}{2}\right) \sim F_{2,(T-\mathrm{K}-1)}$ for $N=1$, and

$\left(\frac{1}{U^{1 / 2}}-1\right)\left(\frac{T-K-1}{2}\right) \sim F_{2 N,(T-\mathrm{K}-1)}$ for $N \geq 2$,

where $U=|\hat{G}| /|\hat{H}+\hat{G}|$.

When $\varepsilon_{t}$ exhibits conditional heteroskedasticity, the GMM method can be used to account for non-normality (Hansen 1982; Ferson, Foerster, and Keim 1993). The moment condition is:

$E\left[g_{t}\right]=E\left[x_{t} \otimes \varepsilon_{t}\right]=0_{(K+1) N}$

where $x_{t}=\left[\begin{array}{ll}1 & R_{1 t}{ }^{\prime}\end{array}\right]^{\prime}$. The GMM Wald test is:

$W_{a}=T \operatorname{vec}\left(\hat{\Theta}^{\prime}\right)^{\prime}\left[\left(A_{T} \otimes I_{N}\right) S_{T}\left(A_{T}^{\prime} \otimes I_{N}\right)\right]^{-1} \operatorname{vec}\left(\hat{\Theta}^{\prime}\right)$

where $S_{T}$ is a consistent estimate of $E\left[g_{t} g_{t}^{\prime}\right]$, and

$A=\left[\begin{array}{cc}1+\hat{a}_{1} & -\hat{\mu}_{1} \hat{V}_{11}^{-1} \\ \hat{b}_{1} & -1_{K^{\prime}} \hat{V}_{11}^{-1}\end{array}\right]$.

$W_{a}$ has an asymptotic $x^{2}$ distribution.

\section{DATA AND VARIABLES}

\section{Data sources}

This study retrieves the returns on Asian and European real estate securities from Datastream real estate securities return indices. The Datastream Asian (European) real estate index with a mnemonic RLESTAS (RLESTER) is a value-weighted index of national real estate securities market indices in Asia (Europe) and designed to track the performance of the securitized real estate market in the entire Asian (European) region.

This study also collects Asian and European common stock market return series with mnemonics TOTMKAS and TOTMKER respectively to investigate the influence of 
trading in the stock market on the diversification benefits of cross-continental real estate assets. The Datastream stock indices are value-weighted indices of individual national stock market indices in Asia (Europe) and designed to track the performance of the stock market in the entire Asian (European) region. This study employs TOTMKAS (TOTMKER) to strip out the general stock market influence from RLESTAS (RLESTER), using the orthogonalized approach adopted by McCue and Kling (1994), Brooks and Tsolacos (1999) and Stevenson (2001).

To test for return uniqueness in Asian and European real estate returns, this study selects U.S. securitized and unsecuritized real estate as the investors' domestic benchmark assets. This study uses the monthly returns of all REITs from the National Association of Real Estate Investment Trusts (NAREIT) to gauge the returns on U.S. securitized real estate. The quarterly NCREIF property returns are used to measure the returns on U.S. unsecuritized real estate. Because the returns on unsecuritized real estate are available only in quarterly frequency, this study compounds all monthly return series into quarterly return series.

All these return series are measured in U.S. dollars as originally provided by their data providers, so they are adjusted for foreign exchange fluctuations from the U.S. investors' perspective (Liow and Sim, 2006). The entire test period is from 1978 to 2005 because the NCREIF property returns starts in 1978.

To check the influence of structural breaks experienced by REITs, we repeat our analyses for 1978:1-1993:4 and 1994:1-2005:4, because the Revenue Reconciliation Act of 1993 was implemented in 1994. To examine the impact to the Asian financial crisis, following Sing, Ho and Mark (2002), we split our samples into 1978:1-1998:1 and 1998:2-2005:4.

\section{Description of variables}

Table 1 reports means and standard deviations of return series of the 4 sample real estate assets. As shown in Panel A, during the entire sample period of 1978-2005, Asian real estate securities yield the highest quarterly mean return, $4.15 \%$, and the highest standard deviation, $15.97 \%$. The quarterly mean return and standard deviation of U.S. REITs are $3.25 \%$ and $7.41 \%$. The NCREIF Index has lower quarterly mean return and standard deviation: $2.40 \%$ and $1.70 \%$ respectively. The quarterly mean returns for European real estate securities was $3.52 \%$. The associated standard deviation was $9.03 \%$. Panels B and $\mathrm{C}$ indicate that REITs experience a slight increase in return and decrease in standard deviation after the 1993 structural break. On the contrary, Asian real estate securities suffer a decrease in return and increase in volatility after the Asian financial crisis. 
Table 1: Means (Standard Deviations)

\begin{tabular}{|c|c|c|c|}
\hline Asia & Europe & NAREIT & NCREIF \\
\hline \multicolumn{4}{|c|}{ Panel A: The entire sample period: $1978: 1$ to $2005: 4$} \\
\hline Asia & Europe & NAREIT & NCREIF \\
\hline $\begin{array}{c}0.0415 \\
(0.1597)\end{array}$ & $\begin{array}{c}0.0352 \\
(0.0903)\end{array}$ & $\begin{array}{c}0.0325 \\
(0.0741)\end{array}$ & $\begin{array}{c}0.0240 \\
(0.0170)\end{array}$ \\
\hline \multicolumn{4}{|c|}{ Panel B: Period before the REIT structural break:1978:1-1993:4 } \\
\hline $\begin{array}{c}0.0549 \\
(0.1603) \\
\end{array}$ & $\begin{array}{c}0.0375 \\
(0.1007) \\
\end{array}$ & $\begin{array}{c}0.0319 \\
(0.0789) \\
\end{array}$ & $\begin{array}{c}0.0217 \\
(0.0203)\end{array}$ \\
\hline \multicolumn{4}{|c|}{ Panel C: Period after the REIT structural break: 1994:1-2005:4 } \\
\hline $\begin{array}{c}0.0236 \\
(0.1589)\end{array}$ & $\begin{array}{c}0.0322 \\
(0.0752)\end{array}$ & $\begin{array}{c}0.0334 \\
(0.0680)\end{array}$ & $\begin{array}{c}0.0270 \\
(0.0108)\end{array}$ \\
\hline \multicolumn{4}{|c|}{ Panel D: Period before the Asian financial crisis:1978:1-1998:1 } \\
\hline $\begin{array}{c}0.0445 \\
(0.1525)\end{array}$ & $\begin{array}{c}0.0367 \\
(0.0934)\end{array}$ & $\begin{array}{c}0.0336 \\
(0.0736)\end{array}$ & $\begin{array}{c}0.0222 \\
(0.0186)\end{array}$ \\
\hline \multicolumn{4}{|c|}{ Panel E: Period after the Asian financial crisis:1998:2-2005:4 } \\
\hline $\begin{array}{c}0.0335 \\
(0.1799) \\
\end{array}$ & $\begin{array}{c}0.0313 \\
(0.0830) \\
\end{array}$ & $\begin{array}{c}0.0298 \\
(0.0765) \\
\end{array}$ & $\begin{array}{c}0.0286 \\
(0.0112)\end{array}$ \\
\hline
\end{tabular}

Note: The reported numbers are based on quarterly returns of Asian real estate securities (Asia), European real estate securities (Europe), the NAREIT Index (NAREIT) and the NCREIF Index (NCREIF).

Tables 2 and 3 report the correlations with NAREIT and NCREIF return series. The correlation structures reveal that U.S. REIT returns are loosely related to international real estate returns. The correlation coefficient between REITs and Asian (European) real estate securities is $20.49 \%$ (22.65\%) over the period from 1978 to 2005 . Consistent with Liow and Sim (2006), Asian real estate securities are become more closely co-moved with REITs, so do European real estate securities as shown in Table 2.

Table 2: Correlation coefficients with NAREIT

\begin{tabular}{|c|c|c|}
\hline Asia & Europe & NCREIF \\
\hline \multicolumn{3}{|c|}{ Panel A: The entire sample period: $1978: 1$ to $2005: 4$} \\
\hline 0.2049 & 0.2265 & -0.0350 \\
\hline \multicolumn{3}{|c|}{ Panel B: Period before the REIT structural break:1978:1-1993:4 } \\
\hline 0.1780 & 0.1399 & -0.0564 \\
\hline \multicolumn{3}{|c|}{ Panel C: Period after the REIT structural break: 1994:1-2005:4 } \\
\hline 0.2533 & 0.4098 & 0.0166 \\
\hline \multicolumn{3}{|c|}{ Panel D: Period before the Asian financial crisis:1978:1-1998:1 } \\
\hline 0.1808 & 0.1408 & -0.0429 \\
\hline \multicolumn{3}{|c|}{ Panel E: Period after the Asian financial crisis:1998:2-2005:4 } \\
\hline 0.2565 & 0.4740 & 0.0127 \\
\hline
\end{tabular}

Note: The reported numbers are based on quarterly returns of Asian real estate securities (Asia), European real estate securities (Europe), the NAREIT Index (NAREIT) and the NCREIF Index (NCREIF). 
Table 3: Correlation coefficients with NCREIF

\begin{tabular}{|c|c|c|}
\hline Asia & Europe & NAREIT \\
\hline \multicolumn{3}{|c|}{ Panel A: The entire sample period: $1978: 1$ to $2005: 4$} \\
\hline-0.0067 & 0.1440 & -0.0350 \\
\hline \multicolumn{3}{|c|}{ Panel B: Period before the REIT structural break:1978:1-1993:4 } \\
\hline 0.0436 & 0.1534 & -0.0564 \\
\hline \multicolumn{3}{|c|}{ Panel C: Period after the REIT structural break: 1994:1-2005:4 } \\
\hline-0.0804 & 0.1467 & 0.0166 \\
\hline \multicolumn{3}{|c|}{ Panel D: Period before the Asian financial crisis:1978:1-1998:1 } \\
\hline-0.0110 & 0.1702 & -0.0429 \\
\hline \multicolumn{3}{|c|}{ Panel E: Period after the Asian financial crisis:1998:2-2005:4 } \\
\hline 0.0336 & 0.0634 & 0.0127 \\
\hline
\end{tabular}

Note: The reported numbers are based on quarterly returns of Asian real estate securities (Asia), European real estate securities (Europe), the NAREIT Index (NAREIT), and the NCREIF Index (NCREIF).

Table 3 shows that U.S. unsecuritized real estate returns even co-move less with international real estate securities than does U.S. securitized real estate. During the whole sample period, the correlation coefficient between the NCREIF Index and Asian real estate securities is $-0.67 \%$ and European real estate securities have a correlation coefficient of $14.40 \%$ with the NCREIF Index. Asia real estate securities appear to comove more closely with U.S. unsecuritized real estate assets after the Asian financial crisis. In contrast, European real estate securities seem to move away from the NCREIF index.

\section{SPANNING TEST RESULTS}

Table 4 presents the spanning test results for cross-continental real estate securities during the 1978:1-2005:4 period. Panel A presents the test results when the test portfolio contains both Asian and European securities. Panel B and Panel C report the results when the international portfolio consists of only Asian and only European real estate securities, respectively. When the benchmark assets consist of only REITs, the $L R, W, L M, F$ and $W_{a}$ test statistics have a value of 42.48 (7.91, 35.45), 50.44 (8.20, 41.70), 36.18 (7.64, 30.39), $11.38(4.03,20.48)$ and $1423.20(7.71,41.46)$ in Panel A $(B, C)$ respectively. These values are all statistically significant at the 5\% level. The result is consistent with Gilberto (1990), Wilson and Okunev (1996), Pierzak (2001) and Bigman (2002) that international real estate securities provide diversification benefits from a U.S. investor's perspective. 
Table 4: Spanning tests with original returns for the period 1978:1-2005:4

$\begin{array}{lllll}L R & W & L M & F & W a\end{array}$

Panel A: Test assets: Asian and European real estate securities

\begin{tabular}{|c|c|c|c|c|}
\hline \multicolumn{5}{|c|}{ Benchmark Assets: NAREIT } \\
\hline $\begin{array}{l}42.48 \\
(0.00)^{* * *}\end{array}$ & $\begin{array}{l}50.44 \\
(0.00) * * *\end{array}$ & $\begin{array}{l}36.18 \\
(0.00)^{* *}\end{array}$ & $\begin{array}{l}11.38 \\
(0.00)^{* * * *}\end{array}$ & $\begin{array}{l}1423.20 \\
(0.00)^{* * *}\end{array}$ \\
\hline \multicolumn{5}{|c|}{ Benchmark Assets: NCREIF } \\
\hline $\begin{array}{c}4.99 \\
(0.29)\end{array}$ & $\begin{array}{c}5.08 \\
(0.28)\end{array}$ & $\begin{array}{c}4.90 \\
(0.30)\end{array}$ & $\begin{array}{c}1.23 \\
(0.30)\end{array}$ & $\begin{array}{c}4.83 \\
(0.30)\end{array}$ \\
\hline \multicolumn{5}{|c|}{ Benchmark Assets: NAREIT and NCREIF } \\
\hline $\begin{array}{c}1.50 \\
(0.83)\end{array}$ & $\begin{array}{c}1.51 \\
(0.83)\end{array}$ & $\begin{array}{c}1.49 \\
(0.83)\end{array}$ & $\begin{array}{c}0.36 \\
(0.84)\end{array}$ & $\begin{array}{c}8.72 \\
(0.07)^{*}\end{array}$ \\
\hline \multicolumn{5}{|c|}{ Panel B: Test assets: Asian real estate securities } \\
\hline \multicolumn{5}{|c|}{ Benchmark Assets: NAREIT } \\
\hline $\begin{array}{c}7.91 \\
(0.02)^{* *}\end{array}$ & $\begin{array}{c}8.20 \\
(0.02)^{* *}\end{array}$ & $\begin{array}{c}7.64 \\
(0.02)^{* *}\end{array}$ & $\begin{array}{c}4.03 \\
(0.02)^{* *}\end{array}$ & $\begin{array}{c}7.71 \\
(0.02)^{* *}\end{array}$ \\
\hline \multicolumn{5}{|c|}{ Benchmark Assets: NAREIT and Europe } \\
\hline $\begin{array}{c}0.29 \\
(0.87)\end{array}$ & $\begin{array}{c}0.29 \\
(0.87)\end{array}$ & $\begin{array}{c}0.29 \\
(0.87)\end{array}$ & $\begin{array}{c}0.14 \\
(0.87)\end{array}$ & $\begin{array}{c}0.29 \\
(0.87)\end{array}$ \\
\hline \multicolumn{5}{|c|}{ Benchmark Assets: NCREIF } \\
\hline $\begin{array}{c}2.76 \\
(0.25)\end{array}$ & $\begin{array}{c}2.80 \\
(0.25)\end{array}$ & $\begin{array}{c}2.73 \\
(0.26)\end{array}$ & $\begin{array}{c}1.37 \\
(0.26)\end{array}$ & $\begin{array}{c}0.46 \\
(0.11)\end{array}$ \\
\hline \multicolumn{5}{|c|}{ Benchmark Assets: NCREIF and Europe } \\
\hline $\begin{array}{c}1.55 \\
(0.46)\end{array}$ & $\begin{array}{c}1.56 \\
(0.46)\end{array}$ & $\begin{array}{c}1.54 \\
(0.46)\end{array}$ & $\begin{array}{c}0.76 \\
(0.47)\end{array}$ & $\begin{array}{c}2.55 \\
(0.28)\end{array}$ \\
\hline \multicolumn{5}{|c|}{ Benchmark Assets: NAREIT and NCREIF } \\
\hline $\begin{array}{c}1.20 \\
(0.55)\end{array}$ & $\begin{array}{c}1.20 \\
(0.55)\end{array}$ & $\begin{array}{c}1.19 \\
(0.55)\end{array}$ & $\begin{array}{c}0.59 \\
(0.56)\end{array}$ & $\begin{array}{c}1.60 \\
(0.45)\end{array}$ \\
\hline \multicolumn{5}{|c|}{ Benchmark Assets: NAREIT, NCREIF and Europe } \\
\hline $\begin{array}{c}0.83 \\
(0.66)\end{array}$ & $\begin{array}{c}0.84 \\
(0.66)\end{array}$ & $\begin{array}{c}0.83 \\
(0.66)\end{array}$ & $\begin{array}{c}0.40 \\
(0.67)\end{array}$ & $\begin{array}{c}1.43 \\
(0.49)\end{array}$ \\
\hline
\end{tabular}

Panel C: Test assets: European real estate securities

Benchmark Assets: NAREIT

\begin{tabular}{|c|c|c|c|c|}
\hline $\begin{array}{l}35.45 \\
(0.00)^{* * *}\end{array}$ & $\begin{array}{l}41.70 \\
(0.00)^{* * *}\end{array}$ & $\begin{array}{l}30.39 \\
(0.00)^{* * *}\end{array}$ & $\begin{array}{l}20.48 \\
(0.00)^{* * *}\end{array}$ & $\begin{array}{l}41.46 \\
(0.00)^{* * *}\end{array}$ \\
\hline \multicolumn{5}{|c|}{ Benchmark Assets: NAREIT and Asia } \\
\hline $\begin{array}{l}27.82 \\
(0.00) * * *\end{array}$ & $\begin{array}{l}31.58 \\
(0.00)^{* * *}\end{array}$ & $\begin{array}{l}24.64 \\
(0.00)^{* * * *}\end{array}$ & $\begin{array}{l}15.37 \\
(0.00)^{* * *}\end{array}$ & $\begin{array}{l}35.89 \\
(0.00)^{* * *}\end{array}$ \\
\hline \multicolumn{5}{|c|}{ Benchmark Assets: NCREIF } \\
\hline $\begin{array}{c}1.99 \\
(0.37)\end{array}$ & $\begin{array}{c}2.01 \\
(0.37)\end{array}$ & $\begin{array}{c}1.97 \\
(0.37)\end{array}$ & $\begin{array}{c}0.99 \\
(0.38)\end{array}$ & $\begin{array}{c}2.27 \\
(0.32)\end{array}$ \\
\hline \multicolumn{5}{|c|}{ Benchmark Assets: NCREIF and Asia } \\
\hline $\begin{array}{c}0.78 \\
(0.68)\end{array}$ & $\begin{array}{c}0.78 \\
(0.68)\end{array}$ & $\begin{array}{c}0.77 \\
(0.68)\end{array}$ & $\begin{array}{c}0.38 \\
(0.69)\end{array}$ & $\begin{array}{c}0.80 \\
(0.70)\end{array}$ \\
\hline \multicolumn{5}{|c|}{ Benchmark Assets: NAREIT and NCREIF } \\
\hline $\begin{array}{c}1.18 \\
(0.55)\end{array}$ & $\begin{array}{c}1.19 \\
(0.55)\end{array}$ & $\begin{array}{c}1.17 \\
(0.56)\end{array}$ & $\begin{array}{c}0.58 \\
(0.56)\end{array}$ & $\begin{array}{c}1.10 \\
(0.58)\end{array}$ \\
\hline \multicolumn{5}{|c|}{ Benchmark Assets: NAREIT, NCREIF and Asia } \\
\hline $\begin{array}{c}0.81 \\
(0.67)\end{array}$ & $\begin{array}{c}0.82 \\
(0.66)\end{array}$ & $\begin{array}{c}0.81 \\
(0.67)\end{array}$ & $\begin{array}{c}0.39 \\
(0.68)\end{array}$ & $\begin{array}{c}0.63 \\
(0.73)\end{array}$ \\
\hline
\end{tabular}

Note: Asia is quarterly return of Asian real estate securities. Europe stands for the quarterly returns of European real estate stocks. NAREIT is quarterly return of NAREIT real estate index. NCREIF stands for the quarterly return of NCREIF index. The $p$-values are in parentheses. Test statistics and their associated $p$-values for the stripped returns are in square and curly brackets respectively. ${ }^{* *}$ Significant at the $1 \%$ level. ${ }^{* *}$ Significant at the $5 \%$ level. *Significant at the $10 \%$ level. 
When the benchmark assets are expanded by including European real estate securities, the addition of Asian real estate stocks does not significantly enhance the efficient frontier. The results suggest that diversifying into Asian real estate securities may be desirable only for a pure U.S. REIT portfolio. In contrast to this, the addition of European real estate securities significantly enhances the efficient frontier when the benchmark assets are expanded by including Asian real estate securities.

In contrast to the REIT-only results, when the benchmark portfolio is expanded to include the NCREIF Index, this set of test results casts doubts on overseas real estate securities diversification. All test statistics except one are statistically insignificant. That is, the NCREIF Index appears to leave no room for international real estate stocks to improve the mean-variance frontier. This extends Chiang and Lee's (2007) result. The authors show that REITs lose their diversification effects when the NCREIF Index is already in mixed-asset portfolios.

It is widely known that the growth of REIT markets and increasing participation by institutional investors resulted in a structural change in the early 1990s (Glascock, Lu and So, 2000; Lee and Lee, 2003). Are our results driven by vintage data prior to the new REIT era? To check this, we repeat our analyses for the following two sub-periods: 1978:1-1993:4 and 1994:1-2005:4. The cutoff point of 1994 is chosen because the Revenue Reconciliation Act of 1993 was implemented that year.

Table 5 presents the results for the period 1978:1-1993:4. Similar to the full sample results, when the benchmark assets consists of only REITs, the $L R, W, L M, F$ and $W_{a}$ test statistics have a value of 30.63 (7.45, 22.66), 36.76 (7.90, 27.20), 25.90 (7.03, 19.09), 8.24 $(3.83,13.17)$ and $994.78(7.96,31.58)$ for the test portfolio containing both Asian and European securities (only Asian real estate stocks, only European real estate stocks) respectively. These values are all statistically significant at the $5 \%$ level.

Similar to the full sample period results, European real estate stocks significantly improve the efficient frontier even when the benchmark assets are expanded by including Asian real estate securities; but Asian real estate stocks do not provide significant diversification when investors have a stake in European real estate securities in addition to REITs. Again, the direct real estate investment seems to leave little room for international real estate securities to improve the mean-variance frontier. All test statistics except two are statistically insignificant for the period 1978:1-1993:4. 
Table 5: Spanning tests with original returns for the period 1978:1-1993:4
$L R$
$W$
$L M$
$\boldsymbol{F}$
$\boldsymbol{W a}$

Panel A: Test assets: Asian and European real estate securities

\begin{tabular}{|c|c|c|c|c|}
\hline \multicolumn{5}{|c|}{ Benchmark Assets: NAREIT } \\
\hline $\begin{array}{l}30.63 \\
(0.00)^{* * *}\end{array}$ & $\begin{array}{l}36.76 \\
(0.00)^{* * *}\end{array}$ & $\begin{array}{l}25.90 \\
(0.00)^{* * * *}\end{array}$ & $\begin{array}{l}8.24 \\
(0.00)^{* * *}\end{array}$ & $\begin{array}{l}994.78 \\
(0.00)^{* * *}\end{array}$ \\
\hline \multicolumn{5}{|c|}{ Benchmark Assets: NCREIF } \\
\hline 4.63 & 4.78 & 4.47 & 1.12 & 33.42 \\
\hline$(0.33)$ & $(0.31)$ & $(0.35)$ & $(0.35)$ & $(0.00)^{* * * *}$ \\
\hline \multicolumn{5}{|c|}{ Benchmark Assets: NAREIT and NCREIF } \\
\hline 2.51 & 2.56 & 2.46 & 0.59 & 8.16 \\
\hline$(0.64)$ & $(0.63)$ & $(0.65)$ & $(0.67)$ & $(0.09)^{*}$ \\
\hline \multicolumn{5}{|c|}{ Panel B: Test assets: Asian real estate securities } \\
\hline \multicolumn{5}{|c|}{ Benchmark Assets: NAREIT } \\
\hline 7.45 & 7.90 & 7.03 & 3.83 & 7.96 \\
\hline$(0.02)^{* *}$ & $(0.02)^{* *}$ & $(0.03)^{* *}$ & $(0.03)^{* *}$ & $(0.02)^{* *}$ \\
\hline \multicolumn{5}{|c|}{ Benchmark Assets: NAREIT and Europe } \\
\hline 1.26 & 1.27 & 1.25 & 0.61 & 1.19 \\
\hline$(0.53)$ & $(0.53)$ & $(0.54)$ & $(0.55)$ & $(0.55)$ \\
\hline \multicolumn{5}{|c|}{ Benchmark Assets: NCREIF } \\
\hline 3.16 & 3.24 & 3.08 & 1.57 & 3.81 \\
\hline$(0.21)$ & $(0.20)$ & $(0.21)$ & $(0.22)$ & $(0.15)$ \\
\hline \multicolumn{5}{|c|}{ Benchmark Assets: NCREIF and Europe } \\
\hline 1.59 & 1.61 & 1.57 & 0.77 & 2.10 \\
\hline$(0.45)$ & $(0.45)$ & $(0.46)$ & $(0.47)$ & $(0.35)$ \\
\hline \multicolumn{5}{|c|}{ Benchmark Assets: NAREIT and NCREIF } \\
\hline 2.22 & 2.26 & 2.18 & 1.08 & 2.20 \\
\hline$(0.33)$ & $(0.32)$ & $(0.34)$ & $(0.35)$ & $(0.33)$ \\
\hline \multicolumn{5}{|c|}{ Benchmark Assets: NAREIT, NCREIF and Europe } \\
\hline 1.14 & 1.15 & 1.13 & 0.54 & 1.29 \\
\hline$(0.57)$ & $(0.56)$ & $(0.57)$ & $(0.59)$ & $(0.52)$ \\
\hline
\end{tabular}

Panel C: Test assets: European real estate securities Benchmark Assets: NAREIT

\begin{tabular}{|c|c|c|c|c|}
\hline $\begin{array}{l}22.66 \\
(0.00)^{* * *}\end{array}$ & $\begin{array}{l}27.20 \\
(0.00)^{* * *}\end{array}$ & $\begin{array}{l}19.09 \\
(0.00)^{* * * *}\end{array}$ & $\begin{array}{l}13.17 \\
(0.00)^{* * * *}\end{array}$ & $\begin{array}{l}31.58 \\
(0.00)^{* * *}\end{array}$ \\
\hline \multicolumn{5}{|c|}{ Benchmark Assets: NAREIT and Asia } \\
\hline $\begin{array}{l}16.48 \\
(0.00)^{* * * *}\end{array}$ & 18.79 & 14.53 & 8.96 & 24.94 \\
\hline \multicolumn{5}{|c|}{ Benchmark Assets: NCREIF } \\
\hline $\begin{array}{c}1.75 \\
(0.42) \\
\end{array}$ & $\begin{array}{c}1.78 \\
(0.41)\end{array}$ & $\begin{array}{l}1.73 \\
(0.42)\end{array}$ & $\begin{array}{c}0.86 \\
(0.43) \\
\end{array}$ & $\begin{array}{c}2.15 \\
(0.34) \\
\end{array}$ \\
\hline \multicolumn{5}{|c|}{ Benchmark Assets: NCREIF and Asia } \\
\hline $\begin{array}{c}0.19 \\
(0.91)\end{array}$ & $\begin{array}{c}0.19 \\
(0.91)\end{array}$ & $\begin{array}{c}0.19 \\
(0.91)\end{array}$ & $\begin{array}{c}0.09 \\
(0.91) \\
\end{array}$ & $\begin{array}{c}0.23 \\
(0.89) \\
\end{array}$ \\
\hline \multicolumn{5}{|c|}{ Benchmark Assets: $\mathrm{N}$} \\
\hline 1.25 & 1.26 & 1.23 & 0.60 & 1.71 \\
\hline$(0.54)$ & $(0.53)$ & $(0.54)$ & $(0.55)$ & $(0.56)$ \\
\hline $\begin{array}{c}0.16 \\
(0.92)\end{array}$ & $\begin{array}{c}0.16 \\
(0.92)\end{array}$ & $\begin{array}{c}0.16 \\
(0.92)\end{array}$ & $\begin{array}{c}0.08 \\
(0.93)\end{array}$ & $\begin{array}{c}0.14 \\
(0.93)\end{array}$ \\
\hline
\end{tabular}

Note: Asia is quarterly return of Asian real estate securities. Europe stands for the quarterly returns of European real estate stocks. NAREIT is quarterly return of NAREIT real estate index. NCREIF stands for the quarterly return of NCREIF index. The $p$-values are in parentheses. Test statistics and their associated $p$-values for the stripped returns are in square and curly brackets respectively. $* *$ Significant at the $1 \%$ level. $* *$ Significant at the $5 \%$ level. *Significant at the $10 \%$ level. 
The spanning test results for the new REIT era are in Table 6. Similar to the test results using vintage era data, the results suggest that investing in a basket of Asian and European real estate securities can be beneficial to U.S. REIT investors in the new REIT era. The corresponding $L R, W, L M, F$ and $W_{a}$ test statistics are all significant at $5 \%$ level and have a value of $13.57,15.69,11.82,3.42$ and 620.84 , respectively. However the results for individual continents reveal a different story. Although the statistics still indicate the potential benefit of European real estate securities for REIT investors, the spanning test results clearly show no diversification advantage for investing in Asian real estate stocks. The $L R, W, L M, F$ and $W_{a}$ test statistics have a value of $1.73,1.76,1.70,0.84$ and 2.38 respectively. These values are not statistical significant at any conventional level. When the benchmark assets contain more than REITs, the test results are similar, as reported in Table 6. Overall, diversifying into Asian real estate securities does not seem to improve investment opportunity sets in the new REIT era.

Before the 1997-1998 Asian financial crisis, Asian real estate securities have been favorites among institutional investors (Mei, 1999). However, the Asian crisis has led U.S. investors to question the usefulness of Asian real estate investment in risk reduction (Mei, 1999). To examine whether this event affects our baseline results, we split our samples into the following sub-periods: 1978:1-1998:1 and 1998:2-2005:4. The selection of this cutoff point follows Sing, Ho and Mark (2002). 
Table 6: Spanning tests with original returns for the period 1994:1-2005:4
$L R$
$W$
$L M$
$\boldsymbol{F}$
$\boldsymbol{W a}$

Panel A: Test assets: Asian and European real estate securities

\begin{tabular}{ccccc}
\hline \multicolumn{5}{c}{ Benchmark Assets: NAREIT } \\
\hline 13.57 & 15.69 & 11.82 & 3.42 & 620.84 \\
$(0.01)^{* * *}$ & $(0.00)^{* * *}$ & $(0.02)^{* *}$ & $(0.01)^{* * *}$ & $(0.01)^{* * *}$ \\
\hline \multicolumn{5}{c}{ Benchmark Assets: NCREIF } \\
\hline 2.45 & 2.49 & 2.42 & 0.58 \\
$(0.65)$ & $(0.65)$ & $(0.66)$ & $(0.68)$ & 115.50 \\
\hline \multicolumn{5}{c}{ Benchmark Assets: NAREIT and NCREIF } \\
\hline 1.34 & 1.35 & 1.32 & 0.31 & $(0.01)^{* * *}$ \\
$(0.86)$ & $(0.85)$ & $(0.86)$ & $(0.87)$ & $(0.55)$ \\
\hline
\end{tabular}

\section{Panel B: Test assets: Asian real estate securities}

Benchmark Assets: NAREIT

\begin{tabular}{ccccc}
1.73 & 1.76 & 1.70 & 0.84 & 2.38 \\
$(0.42)$ & $(0.41)$ & $(0.43)$ & $(0.44)$ & $(0.30)$ \\
\hline
\end{tabular}

\begin{tabular}{|c|c|c|c|c|}
\hline \multicolumn{5}{|c|}{ Benchmark Assets: NAREIT and Europe } \\
\hline 0.19 & 0.19 & 0.19 & 0.09 & 0.22 \\
\hline$(0.91)$ & $(0.91)$ & $(0.91)$ & $(0.92)$ & $(0.90)$ \\
\hline \multicolumn{5}{|c|}{ Benchmark Assets: NCREIF } \\
\hline 1.07 & 1.08 & 1.06 & 0.52 & 1.23 \\
\hline$(0.59)$ & $(0.58)$ & $(0.59)$ & $(0.60)$ & $(0.54)$ \\
\hline \multicolumn{5}{|c|}{ Benchmark Assets: NCREIF and Europe } \\
\hline 1.41 & 1.43 & 1.39 & 0.67 & 1.21 \\
\hline$(0.50)$ & $(0.49)$ & $(0.50)$ & $(0.52)$ & $(0.55)$ \\
\hline \multicolumn{5}{|c|}{ Benchmark Assets: NAREIT and NCREIF } \\
\hline 0.75 & 0.75 & 0.74 & 0.35 & 0.73 \\
\hline$(0.69)$ & $(0.69)$ & $(0.69)$ & $(0.71)$ & $(0.69)$ \\
\hline \multicolumn{5}{|c|}{ Benchmark Assets: NAREIT, NCREIF and Europe } \\
\hline 1.20 & 1.21 & 1.18 & 0.56 & 1.15 \\
\hline$(0.55)$ & $(0.55)$ & $(0.55)$ & $(0.58)$ & $(0.56)$ \\
\hline \multicolumn{5}{|c|}{ Panel C: Test assets: European real estate securities } \\
\hline \multicolumn{5}{|c|}{ Benchmark Assets: NAREIT } \\
\hline 12.37 & 14.11 & 10.90 & 6.76 & 12.31 \\
\hline$(0.00)^{* * *}$ & $(0.00)^{* * *}$ & $(0.00)^{* * *}$ & $(0.00) * * *$ & $(0.00)^{* * *}$ \\
\hline \multicolumn{5}{|c|}{ Benchmark Assets: NAREIT and Asia } \\
\hline 10.83 & 12.15 & 9.69 & 5.69 & 11.32 \\
\hline$(0.00)^{* * *}$ & $(0.00)^{* * *}$ & $(0.01)^{* *}$ & $(0.01)^{* *}$ & $(0.00) * * *$ \\
\hline \multicolumn{5}{|c|}{ Benchmark Assets: NCREIF } \\
\hline 0.24 & 0.24 & 0.24 & 0.11 & 0.23 \\
\hline$(0.89)$ & $(0.89)$ & $(0.89)$ & $(0.89)$ & $(0.89)$ \\
\hline \multicolumn{5}{|c|}{ Benchmark Assets: NCREIF and Asia } \\
\hline 0.57 & 0.58 & 0.57 & 0.27 & 0.42 \\
\hline$(0.75)$ & $(0.75)$ & $(0.75)$ & $(0.76)$ & $(0.81)$ \\
\hline \multicolumn{5}{|c|}{ Benchmark Assets: NAREIT and NCREIF } \\
\hline 0.28 & 0.28 & 0.27 & 0.13 & 0.22 \\
\hline$(0.87)$ & $(0.87)$ & $(0.87)$ & $(0.88)$ & $(0.90)$ \\
\hline \multicolumn{5}{|c|}{ Benchmark Assets: NAREIT, NCREIF and Asia } \\
\hline 0.73 & 0.73 & 0.72 & 0.34 & 0.51 \\
\hline$(0.69)$ & $(0.69)$ & $(0.70)$ & $(0.72)$ & $(0.77)$ \\
\hline
\end{tabular}

Note: Asia is quarterly return of Asian real estate securities. Europe stands for the quarterly returns of European real estate stocks. NAREIT is quarterly return of NAREIT real estate index. NCREIF stands for the quarterly return of NCREIF index. The $p$-values are in parentheses. Test statistics and their associated $p$-values for the stripped returns are in square and curly brackets respectively. $* *$ Significant at the $1 \%$ level. $* *$ Significant at the $5 \%$ level. *Significant at the $10 \%$ level. 
Table 7: Spanning tests with original returns for the period 1978:1-1998:1
$L R$
$W$
$L M$
$\boldsymbol{F}$
$\boldsymbol{W a}$

Panel A: Test assets: Asian and European real estate securities

Benchmark Assets: NAREIT

\begin{tabular}{ccccc}
$\begin{array}{l}36.31 \\
(0.00) * * *\end{array}$ & $\begin{array}{l}44.53 \\
(0.00) * * *\end{array}$ & $\begin{array}{l}30.57 \\
(0.00) * * *\end{array}$ & $\begin{array}{c}9.89 \\
(0.00) * * *\end{array}$ & $\begin{array}{r}1143.90 \\
(0.00)^{* * *}\end{array}$ \\
\hline \multicolumn{5}{c}{ Benchmark Assets: NCREIF } \\
$(0.30)$ & 5.00 & 4.73 & 1.19 & 4.41 \\
\multicolumn{5}{c}{} \\
\hline 2.08 & $(0.29)$ & $(0.32)$ & $(0.32)$ & $(0.35)$ \\
$(0.72)$ & 2.11 & 2.05 & 0.50 & 9.29 \\
\hline
\end{tabular}

Panel B: Test assets: Asian real estate securities

Benchmark Assets: NAREIT

\begin{tabular}{ccccc}
7.69 & 8.06 & 7.33 & 3.93 & 8.06 \\
$(0.02)^{* *}$ & $(0.02)^{* *}$ & $(0.03)^{* *}$ & $(0.02)^{* *}$ & $(0.02)^{* *}$ \\
\hline
\end{tabular}

\begin{tabular}{ccccc}
\multicolumn{5}{c}{ Benchmark Assets: NAREIT and Europe } \\
0.38 & 0.38 & 0.37 & 0.18 & 0.35 \\
$(0.83)$ & $(0.83)$ & $(0.83)$ & $(0.83)$ & $(0.84)$
\end{tabular}

\begin{tabular}{|c|c|c|c|c|}
\hline \multicolumn{5}{|c|}{ Benchmark Assets: NCREIF } \\
\hline $\begin{array}{c}3.12 \\
(0.21)\end{array}$ & $\begin{array}{c}3.18 \\
(0.20)\end{array}$ & $\begin{array}{c}3.06 \\
(0.22)\end{array}$ & $\begin{array}{c}1.55 \\
(0.22)\end{array}$ & $\begin{array}{c}4.42 \\
(0.11)\end{array}$ \\
\hline \multicolumn{5}{|c|}{ Benchmark Assets: NCREIF and Europe } \\
\hline 1.96 & $\begin{array}{c}1.99 \\
037\end{array}$ & $\begin{array}{c}1.94 \\
(038)\end{array}$ & 0.96 & 2.66 \\
\hline \multicolumn{5}{|c|}{ Benchmark Assets: NAREIT and NCREIF } \\
\hline 1.57 & 1.58 & 1.55 & 0.76 & 1.86 \\
\hline \multicolumn{5}{|c|}{ Benchmark Assets: NAREIT, NCREIF and Europe } \\
\hline 1.03 & 1.03 & 1.02 & 0.49 & 1.39 \\
\hline$(0.60)$ & $(0.60)$ & $(0.60)$ & $(0.61)$ & $(0.50)$ \\
\hline \multicolumn{5}{|c|}{ Panel C: Test assets: European real estate securities } \\
\hline \multicolumn{5}{|c|}{ Benchmark Assets: NAREIT } \\
\hline $\begin{array}{l}28.86 \\
(0.00)^{* * * *}\end{array}$ & $\begin{array}{l}34.67 \\
(0.00) * * *\end{array}$ & $\begin{array}{l}24.28 \\
(0.00)^{*} * *\end{array}$ & $\begin{array}{l}16.91 \\
(0.00)^{* * * *}\end{array}$ & $\begin{array}{l}37.96 \\
(0.00) * * *\end{array}$ \\
\hline \multicolumn{5}{|c|}{ Benchmark Assets: NAREIT and Asia } \\
\hline 21.55 & 24.69 & 18.92 & 11.89 & 31.33 \\
\hline$(0.00)^{* * *}$ & $(0.00) * * *$ & $(0.00)^{* * *}$ & $(0.00)^{* * *}$ & $(0.00)^{* * *}$ \\
\hline \multicolumn{5}{|c|}{ Benchmark Assets: NCREIF } \\
\hline 2.07 & 2.10 & 2.05 & 1.02 & 2.32 \\
\hline$(0.35)$ & $(0.35)$ & $(0.36)$ & $(0.36)$ & $(0.31)$ \\
\hline \multicolumn{5}{|c|}{ Benchmark Assets: NCREIF and Asia } \\
\hline 0.91 & 0.92 & 0.91 & 0.44 & 0.71 \\
\hline$(0.63)$ & $(0.63)$ & $(0.64)$ & $(0.64)$ & $(0.70)$ \\
\hline \multicolumn{5}{|c|}{ Benchmark Assets: NAREIT and NCREIF } \\
\hline 1.50 & 1.51 & 1.48 & 0.73 & 1.34 \\
\hline$(0.47)$ & $(0.47)$ & $(0.48)$ & $(0.48)$ & $(0.51)$ \\
\hline \multicolumn{5}{|c|}{ Benchmark Assets: NAREIT, NCREIF and Asia } \\
\hline 0.96 & 0.96 & 0.95 & 0.46 & 0.66 \\
\hline$(0.62)$ & $(0.62)$ & $(0.62)$ & $(0.64)$ & $(0.72)$ \\
\hline
\end{tabular}

Note: Asia is quarterly return of Asian real estate securities. Europe stands for the quarterly returns of European real estate stocks. NAREIT is quarterly return of NAREIT real estate index. NCREIF stands for the quarterly return of NCREIF index. The $p$-values are in parentheses. Test statistics and their associated $p$-values for the stripped returns are in square and curly brackets respectively. $* *$ Significant at the $1 \%$ level. $* *$ Significant at the $5 \%$ level. *Significant at the $10 \%$ level. 
Table 7 shows the results for the period before the Asian crisis. When the test asset contains only Asian real estate securities and the benchmark asset consists of only REITs, the $L R, W, L M, F$ and $W_{a}$ test statistics have a value of $7.69,8.06,7.33,3.93$ and 8.06, respectively. These values are all statistically significant at the 5\% level. The results are consistent with practitioners' perception, as observed by Mei (1999), that Asian real estate securities provide beneficial diversification opportunities. Nevertheless, similar to the results reported earlier, this diversification benefit diminishes when the NCREIF Index or European real estate stocks are included into portfolios. The results for European real estate securities are similar to the earlier results that European real estate stocks provide significant diversification benefit to U.S. REIT/ Asian real estate stock investors.

Table 8 presents test results for the period after the crisis. The results for investing both Asian and European real estate stocks together are slightly different from those reported earlier. Particularly when benchmark assets consist of only REITs, the $L R, W, L M, F$ and $W_{a}$ test statistics have a lower value of $7.58,8.56,6.76,1.82$ and 353.60 respectively. Two of the statistics are significant and the rest are only near significant at the $10 \%$ level. The results are likely caused by the vanishing of Asian diversification benefit according to the spanning test results of individual continents. When the test asset contains only Asian real estate securities, the results are similar to those reported in Table 6 for the new REIT era. The $L R, W, L M, F$ and $W_{a}$ test statistics have a lower value of $0.94,0.96,0.93,0.45$ and 1.02, respectively when benchmark assets consist of only REITs. All these values are not statistically significant at any conventional level. In addition, with other specifications of benchmark assets, spanning tests yield no evidence indicating that Asian real estate securities provide diversification benefits. Together, the results in Tables 7 and 8 seem to confirm U.S. investors' suspicion about whether investing in Asian real estate stocks adds value (Mei, 1999). Once more the spanning test results during 1998:2-2005:4 are similar to those in other periods. Overall, the test statistics support that European real estate stocks provide significant diversification benefit to U.S. REIT/Asian real estate stock investors during this period as well as other periods. 
Table 8: Spanning tests with original returns for the period 1998:2-2005:4
$L R$
$W$
$L M$
$\boldsymbol{F}$
Wa

Panel A: Test assets: Asian and European real estate securities

\begin{tabular}{ccccc}
\hline \multicolumn{5}{c}{ Benchmark Assets: NAREIT } \\
\hline 7.58 & 8.56 & 6.76 & 1.82 & 353.60 \\
$(0.11)$ & $(0.07)^{*}$ & $(0.15)$ & $(0.14)$ & $(0.00)^{* * *}$ \\
\hline \multicolumn{5}{c}{ Benchmark Assets: NCREIF } \\
\hline 0.82 & 0.83 & 0.81 & 0.19 \\
$(0.94)$ & $(0.93)$ & $(0.94)$ & $(0.94)$ & $(0.66)$ \\
\hline \multicolumn{5}{c}{ Benchmark Assets: NAREIT and NCREIF } \\
\hline 0.07 & 0.07 & 0.07 & 0.01 & 0.32 \\
$(1.00)$ & $(1.00)$ & $(1.00)$ & $(1.00)$ & $(0.99)$ \\
\hline
\end{tabular}

Panel B: Test assets: Asian real estate securities

Benchmark Assets: NAREIT
0.94
0.96
0.93
0.45
1.02
$(0.62)$
(0.62)
(0.63)
$(0.64)$
$(0.60)$

\begin{tabular}{|c|c|c|c|c|}
\hline \multicolumn{5}{|c|}{ Benchmark Assets: NAREIT and Europe } \\
\hline $\begin{array}{c}0.01 \\
(1.00)\end{array}$ & $\begin{array}{c}0.01 \\
(1.00)\end{array}$ & $\begin{array}{c}0.01 \\
(1.00)\end{array}$ & $\begin{array}{c}0.00 \\
(1.00)\end{array}$ & $\begin{array}{c}0.01 \\
(1.00)\end{array}$ \\
\hline \multicolumn{5}{|c|}{ Benchmark Assets: NCREIF } \\
\hline 0.05 & 0.05 & 0.05 & 0.02 & 0.10 \\
\hline$(0.98)$ & $(0.98)$ & $(0.98)$ & $(0.98)$ & $(0.95)$ \\
\hline \multicolumn{5}{|c|}{ Benchmark Assets: NCREIF and Europe } \\
\hline 0.01 & 0.01 & 0.01 & 0.00 & 0.01 \\
\hline$(1.00)$ & $(1.00)$ & $(1.00)$ & $(1.00)$ & $(1.00)$ \\
\hline \multicolumn{5}{|c|}{ Benchmark Assets: NAREIT and NCREIF } \\
\hline 0.02 & 0.02 & 0.02 & 0.01 & 0.02 \\
\hline$(0.99)$ & $(0.99)$ & $(0.99)$ & $(0.99)$ & $(0.99)$ \\
\hline \multicolumn{5}{|c|}{ Benchmark Assets: NAREIT, NCREIF and Europe } \\
\hline 0.01 & 0.01 & 0.01 & 0.01 & 0.01 \\
\hline$(0.99)$ & $(0.99)$ & $(0.99)$ & $(0.99)$ & $(0.99)$ \\
\hline \multicolumn{5}{|c|}{ Panel C: Test assets: European real estate securities } \\
\hline \multicolumn{5}{|c|}{ Benchmark Assets: NAREIT } \\
\hline 7.13 & 8.01 & 6.37 & 3.75 & 7.16 \\
\hline$(0.03)^{* *}$ & $(0.02) * *$ & $(0.04)^{* *}$ & $(0.04)^{* *}$ & $(0.03)^{* *}$ \\
\hline \multicolumn{5}{|c|}{ Benchmark Assets: NAREIT and Asia } \\
\hline 6.19 & 6.85 & 5.61 & 3.09 & 6.44 \\
\hline$(0.05)^{* *}$ & $(0.03)^{* *}$ & $(0.06)^{*}$ & $(0.06)^{*}$ & $(0.04)^{* *}$ \\
\hline \multicolumn{5}{|c|}{ Benchmark Assets: NCREIF } \\
\hline 0.19 & 0.19 & 0.19 & 0.09 & 0.19 \\
\hline$(0.91)$ & $(0.91)$ & $(0.91)$ & $(0.91)$ & $(0.91)$ \\
\hline \multicolumn{5}{|c|}{ Benchmark Assets: NCREIF and Asia } \\
\hline 0.15 & 0.15 & 0.15 & 0.07 & 0.15 \\
\hline$(0.93)$ & $(0.93)$ & $(0.93)$ & $(0.93)$ & $(0.93)$ \\
\hline \multicolumn{5}{|c|}{ Benchmark Assets: NAREIT and NCREIF } \\
\hline 0.03 & 0.03 & 0.03 & 0.01 & 0.03 \\
\hline$(0.99)$ & $(0.99)$ & $(0.99)$ & $(0.99)$ & $(0.99)$ \\
\hline \multicolumn{5}{|c|}{ Benchmark Assets: NAREIT, NCREIF and Asia } \\
\hline 0.02 & 0.02 & 0.02 & 0.01 & 0.02 \\
\hline$(0.99)$ & $(0.99)$ & $(0.99)$ & $(0.99)$ & $(0.99)$ \\
\hline
\end{tabular}

\footnotetext{
Note: Asia is quarterly return of Asian real estate securities. Europe stands for the quarterly returns of European real estate stocks. NAREIT is quarterly return of NAREIT real estate index. NCREIF stands for the quarterly return of NCREIF index. The $p$-values are in parentheses. Test statistics and their associated $p$-values for the stripped returns are in square and curly brackets respectively. ${ }^{* *}$ Significant at the $1 \%$ level. ${ }^{* *}$ Significant at the $5 \%$ level. *Significant at the $10 \%$ level.
} 
To investigate the influence of general stock markets on the diversification benefits of cross-continental real estate securities, this study stripped out the stock market effects following Stevenson (2001), Books and Tsolacos (1999), McCue and Kling (1994). Tables 9 to 13 report the same analyses of Tables 4-8 with original Asian and European returns replaced with orthogonalized returns. Every panel of Tables 9 to 13, except for Panel B of Tables 11 and 13, have statistics that are at least statistically significant at the $10 \%$ level. This indicates that, after removing the influence of their respective equity market, cross-continental real estate securities provide significant diversification benefits regardless of whether U.S. investors already hold direct real estate assets in their domestic portfolios. This complements Stevenson (2002) for the period 1980 to 1997 . He documents that international real estate securities, when hedged from the equity market influence, can increase Sharpe ratios of U.S. REIT investors' portfolios, but cannot improve portfolio performance when unhedged.

However, the diversification gain may diminish for Asian real estate stocks after the REIT structural breaks and after the Asian financial crisis as shown in Panel B of Tables 11 and 13. This is true particularly when investors hold direct real estate investment already. During these periods, investors benefit from investing in orthogonalized Asian real estate securities only when REITs are the only asset in their domestic portfolios. The results from orthogonalized returns reveal that cross-continental diversification benefits of real estate securities, whenever they exist, appear to come from their underlying direct real estate markets. It appears that trading noise in the equity markets could cause Asian and European real estate securities to deviate from their real estate fundamentals and thus reduce the diversification benefits to U.S. real estate investors. 
Table 9: Tests with orthogonalized returns for the period 1978:1-2005:4
LR
$W$
$L M$
$F$
$\boldsymbol{W a}$

Panel A: Test assets: Orthogonalized Asian and European real estate securities

\begin{tabular}{|c|c|c|c|c|}
\hline \multicolumn{5}{|c|}{ Benchmark Assets: NAREIT } \\
\hline 106.26 & 176.80 & 68.61 & 33.08 & 9377.10 \\
\hline$(0.00) * * *$ & $(0.00) * * *$ & $(0.00) * * *$ & $(0.00) * * *$ & $(0.00) * * *$ \\
\hline \multicolumn{5}{|c|}{ Benchmark Assets: NCREIF } \\
\hline 17.93 & 19.42 & 16.59 & 4.54 & 525.80 \\
\hline$(0.00)^{* * *}$ & $(0.00)^{* * *}$ & $(0.00)^{* * *}$ & $(0.00)^{* * *}$ & $(0.00)^{* * *}$ \\
\hline \multicolumn{5}{|c|}{ Benchmark Assets: NAREIT and NCREIF } \\
\hline 15.09 & 16.16 & 14.12 & 3.76 & 155.633 \\
\hline$(0.00) * * *$ & $(0.00) * * *$ & $(0.00)^{* * *}$ & $(0.01)^{* * *}$ & $(0.00)^{* * *}$ \\
\hline \multicolumn{5}{|c|}{ Panel B: Test assets: Orthogonalized Asian real estate securities } \\
\hline \multicolumn{5}{|c|}{ Benchmark Assets: NAREIT } \\
\hline 40.09 & 48.20 & 33.70 & 23.67 & 50.21 \\
\hline$(0.00) * * *$ & $(0.00) * * *$ & $(0.00)^{* * *}$ & $(0.00)^{* * *}$ & $(0.00) * * *$ \\
\hline \multicolumn{5}{|c|}{ Benchmark Assets: NAREIT and orthogonalized Europe } \\
\hline 11.59 & 12.21 & 11.01 & 5.94 & 12.72 \\
\hline$(0.00)^{* * *}$ & $(0.00)^{* * *}$ & $(0.00)^{* * *}$ & $(0.00)^{* * *}$ & $(0.00)^{* * *}$ \\
\hline \multicolumn{5}{|c|}{ Benchmark Assets: NCREIF } \\
\hline 9.17 & 9.56 & 8.81 & 4.69 & 8.71 \\
\hline$(0.01)^{* * *}$ & $(0.01)^{* * *}$ & $(0.01)^{* * *}$ & $(0.01)^{* * *}$ & $(0.01)^{* * *}$ \\
\hline \multicolumn{5}{|c|}{ Benchmark Assets: NCREIF and orthogonalized Europe } \\
\hline 5.38 & 5.52 & 5.26 & 2.68 & 5.47 \\
\hline$(0.07)^{*}$ & $(0.06)^{*}$ & $(0.07)^{*}$ & $(0.07)^{*}$ & $(0.07)^{*}$ \\
\hline \multicolumn{5}{|c|}{ Benchmark Assets: NAREIT and NCREIF } \\
\hline 8.81 & 9.17 & 8.47 & 4.46 & 8.33 \\
\hline$(0.01)^{* * *}$ & $(0.01)^{* * *}$ & $(0.01)^{* * *}$ & $(0.01)^{* * *}$ & $(0.02)^{* *}$ \\
\hline
\end{tabular}

Panel B: Test assets: Orthogonalized Asian real estate securities
48.20
33.70
23.67
50.21

Benchmark Assets: NAREIT and orthogonalized Europe
5.19
5.31
5.07
2.56
5.31
$(0.07)^{*}$
$(0.07)^{*}$
$(0.08)^{*}$
$(0.08)^{*}$
$(0.02)^{* *}$

Panel C: Test assets: Orthogonalized European real estate securities
97.13
154.60
$(0.00)^{* * *}$
$(0.00)^{* * * *}$
64.95
75.92
179.35
$(0.00)^{* * *}$
$(0.00)^{* * *}$
$(0.00)^{* * *}$

Benchmark Assets: NAREIT

Benchmark Assets: NAREIT and orthogonalized Asia

\begin{tabular}{llccc}
68.63 & 94.70 & 51.31 & 46.08 & 143.17 \\
$(0.00)^{* * *}$ & $(0.00)^{* * *}$ & $(0.00)^{* * *}$ & $(0.00)^{* * *}$ & $(0.00)^{* * *}$ \\
\hline \multicolumn{5}{c}{ Benchmark Assets: NCREIF } \\
\hline
\end{tabular}

\begin{tabular}{|c|c|c|c|c|}
\hline $\begin{array}{l}17.90 \\
(0.00)^{* * *}\end{array}$ & $\begin{array}{l}19.41 \\
(0.00)^{* * *}\end{array}$ & $\begin{array}{l}16.45 \\
(0.00)^{* * *}\end{array}$ & $\begin{array}{l}9.53 \\
(0.00)^{* * *}\end{array}$ & $\begin{array}{l}17.82 \\
(0.00)^{* * *}\end{array}$ \\
\hline
\end{tabular}

14.11

Benchma

$(0.00)^{* * *}$

$(0.00)^{* * *}$

$(0.00)^{* * *}$

$(0.00)^{* * *}$

15.03

13.26

7.32

13.93

$(0.00) * * *$

$(0.00)^{* * *}$

$(0.00)^{* * *}$

$(0.00)^{* * *}$

Benchmark Assets: NAREIT and NCREIF

$\begin{array}{lllcc}18.09 & 19.63 & 16.71 & 9.55 & 18.13 \\ (0.00)^{* * *} & (0.00)^{* * *} & (0.00)^{* * *} & (0.00)^{* * *} & (0.00)^{* * *}\end{array}$

Benchmark Assets: NAREIT, NCREIF and orthogonalized Asia
14.47
15.45
13.57
7.45
14.34
$(0.00) * * *$
$(0.00)^{* * * *}$
$(0.00)^{* * *}$
$(0.00) * * *$
$(0.00) * * *$

Note: Asia is quarterly return of Asian real estate securities. Europe stands for the quarterly returns of European real estate stocks. NAREIT is quarterly return of NAREIT real estate index. NCREIF stands for the quarterly return of NCREIF index. The $p$-values are in parentheses. Test statistics and their associated $p$-values for the stripped returns are in square and curly brackets respectively. $* *$ Significant at the $1 \%$ level. $* *$ Significant at the $5 \%$ level. *Significant at the $10 \%$ level. 
Table 10: Tests with orthogonalized returns for the period 1978:1-1993:4
$L R$
$W$
$L M$
$F$
$\boldsymbol{W a}$

Panel A: Test assets: Orthogonalized Asian and European real estate securities

\begin{tabular}{|c|c|c|c|c|}
\hline \multicolumn{5}{|c|}{ Benchmark Assets: NAREIT } \\
\hline 74.96 & 142.48 & 44.16 & 24.28 & 7846.30 \\
\hline$(0.00)^{* * *}$ & $(0.00)^{* * *}$ & $(0.00)^{* *}$ & $(0.00) * *$ & $(0.00)^{* *}$ \\
\hline \multicolumn{5}{|c|}{ Benchmark Assets: NCREIF } \\
\hline 11.01 & 12.00 & 10.12 & 2.74 & 240.04 \\
\hline$(0.03)^{* *}$ & $(0.02)^{* *}$ & $(0.04)^{* *}$ & $(0.03)^{* *}$ & $(0.00)^{* *}$ \\
\hline \multicolumn{5}{|c|}{ Benchmark Assets: NAREIT and NCREIF } \\
\hline 10.41 & 11.30 & 9.61 & 2.54 & 66.84 \\
\hline$(0.03)^{* *}$ & $(0.02)^{* *}$ & $(0.05)^{* *}$ & $(0.04)^{* *}$ & $(0.00)^{* *}$ \\
\hline \multicolumn{5}{|c|}{ Panel B: Test assets: Orthogonalized Asian real estate securities } \\
\hline \multicolumn{5}{|c|}{ Benchmark Assets: NAREIT } \\
\hline 31.44 & 40.60 & 24.84 & 19.66 & 35.77 \\
\hline$(0.01)^{* * *}$ & $(0.01)^{* * *}$ & $(0.01)^{* * *}$ & $(0.01)^{* * *}$ & $(0.00) * * *$ \\
\hline \multicolumn{5}{|c|}{ Benchmark Assets: NAREIT and orthogonalized Europe } \\
\hline 16.68 & 19.06 & 14.69 & 9.08 & 22.33 \\
\hline$(0.01)^{* * *}$ & $(0.01)^{* * *}$ & $(0.01)^{* * *}$ & $(0.01)^{* * *}$ & $(0.00)^{* * *}$ \\
\hline \multicolumn{5}{|c|}{ Benchmark Assets: NCREIF } \\
\hline 5.45 & 5.69 & 5.22 & 2.75 & 5.18 \\
\hline$(0.07)^{*}$ & $(0.06)^{*}$ & $(0.07)^{*}$ & $(0.07)^{*}$ & $(0.08)^{*}$ \\
\hline \multicolumn{5}{|c|}{ Benchmark Assets: NCREIF and orthogonalized Europe } \\
\hline 5.44 & 5.67 & 5.21 & 2.70 & 5.76 \\
\hline$(0.07)^{*}$ & $(0.06)^{*}$ & $(0.07)^{*}$ & $(0.08)^{*}$ & $(0.06)^{*}$ \\
\hline \multicolumn{5}{|c|}{ Benchmark Assets: NAREIT and NCREIF } \\
\hline 5.34 & 5.56 & 5.12 & 2.65 & 4.80 \\
\hline$(0.07)^{*}$ & $(0.06)^{*}$ & $(0.08)^{*}$ & $(0.08)^{*}$ & $(0.09)^{*}$ \\
\hline
\end{tabular}

\begin{tabular}{|c|c|c|c|c|}
\hline \multicolumn{5}{|c|}{ Benchmark Assets: NAREIT, NCREIF and orthogonalized Europe } \\
\hline 5.34 & 5.56 & 5.12 & 2.61 & 5.32 \\
\hline$(0.07)^{*}$ & $(0.06)^{*}$ & $(0.08)^{*}$ & $(0.08)^{*}$ & $(0.07)^{*}$ \\
\hline \multicolumn{5}{|c|}{ Panel C: Test assets: Orthogonalized European real estate securities } \\
\hline \multicolumn{5}{|c|}{ Benchmark Assets: NAREIT } \\
\hline 58.49 & 95.61 & 38.34 & 46.31 & 96.54 \\
\hline$(0.00)^{* * *}$ & $(0.00)^{* * *}$ & $(0.00) * * *$ & $(0.00) * * *$ & $(0.00)^{* * *}$ \\
\hline \multicolumn{5}{|c|}{ Benchmark Assets: NAREIT and orthogonalized Asia } \\
\hline 43.73 & 62.74 & 31.68 & 29.90 & 81.39 \\
\hline$(0.00)^{* * *}$ & $(0.00)^{* * *}$ & $(0.00)^{* * *}$ & $(0.00)^{* * *}$ & $(0.00)^{* * *}$ \\
\hline \multicolumn{5}{|c|}{ Benchmark Assets: NCREIF } \\
\hline 8.45 & 9.03 & 7.91 & 4.37 & 7.54 \\
\hline$(0.01) * * *$ & $(0.01)^{* * *}$ & $(0.02)^{* *}$ & $(0.02)^{* *}$ & $(0.02) * *$ \\
\hline \multicolumn{5}{|c|}{ Benchmark Assets: NCREIF and orthogonalized Asia } \\
\hline 8.44 & 9.02 & 7.90 & 4.30 & 7.61 \\
\hline$(0.01)^{* * *}$ & $(0.01)^{* * *}$ & $(0.02) * * *$ & $(0.02) * * *$ & $(0.02)^{* *}$ \\
\hline \multicolumn{5}{|c|}{ Benchmark Assets: NAREIT and NCREIF } \\
\hline 8.38 & 8.96 & 7.86 & 4.27 & 7.43 \\
\hline$(0.02)^{* * *}$ & $(0.01)^{* * *}$ & $(0.02)^{* * *}$ & $(0.02)^{* * *}$ & $(0.02)^{* *}$ \\
\hline \multicolumn{5}{|c|}{ Benchmark Assets: NAREIT, NCREIF and orthogonalized Asia } \\
\hline 8.38 & 8.96 & 7.86 & 4.20 & 7.57 \\
\hline$(0.02)^{* * *}$ & $(0.01)^{* * *}$ & $(0.02) * * *$ & $(0.02) * * *$ & $(0.02)^{* *}$ \\
\hline
\end{tabular}


Table 11: Tests with orthogonalized returns for the period 1994:1-2005:4
$L R$
$W$
$L M$
$F$
$\boldsymbol{W a}$

Panel A: Test assets: Orthogonalized Asian and European real estate securities

\begin{tabular}{|c|c|c|c|c|}
\hline \multicolumn{5}{|c|}{ Benchmark Assets: NAREIT } \\
\hline 37.22 & 55.05 & 26.44 & 10.66 & 2876.10 \\
\hline$(0.00)^{* * *}$ & $(0.00) * * *$ & $(0.00)^{* * *}$ & $(0.00) * * *$ & $(0.00)^{* *}$ \\
\hline \multicolumn{5}{|c|}{ Benchmark Assets: NCREIF } \\
\hline 13.81 & 15.84 & 12.12 & 3.48 & 556.26 \\
\hline$(0.01)^{* *}$ & $(0.00)^{* *}$ & $(0.02)^{* * *}$ & $(0.01)^{* * *}$ & $(0.00)^{* *}$ \\
\hline \multicolumn{5}{|c|}{ Benchmark Assets: NAREIT and NCREIF } \\
\hline 11.12 & 12.46 & 9.97 & 2.70 & 123.74 \\
\hline$(0.03)^{* *}$ & $(0.01)^{* * *}$ & $(0.04)^{* *}$ & $(0.04) * *$ & $(0.00)^{* *}$ \\
\hline \multicolumn{5}{|c|}{ Panel B: Test assets: Orthogonalized Asian real estate securities } \\
\hline \multicolumn{5}{|c|}{ Benchmark Assets: NAREIT } \\
\hline 10.04 & 11.16 & 9.06 & 5.35 & 23.09 \\
\hline$(0.01)^{* * *}$ & $(0.00) * * *$ & $(0.01)^{* * *}$ & $(0.01)^{* * *}$ & $(0.00) * * *$ \\
\hline \multicolumn{5}{|c|}{ Benchmark Assets: NAREIT and orthogonalized Europe } \\
\hline 0.58 & 0.59 & 0.58 & 0.27 & 0.62 \\
\hline$(0.75)$ & $(0.75)$ & $(0.75)$ & $(0.76)$ & $(0.73)$ \\
\hline \multicolumn{5}{|c|}{ Benchmark Assets: NCREIF } \\
\hline 4.06 & 4.24 & 3.90 & 2.03 & 3.77 \\
\hline$(0.13)$ & $(0.12)$ & $(0.14)$ & $(0.14)$ & $(0.15)$ \\
\hline \multicolumn{5}{|c|}{ Benchmark Assets: NCREIF and orthogonalized Europe } \\
\hline 0.90 & 0.91 & 0.89 & 0.43 & 1.40 \\
\hline$(0.64)$ & $(0.64)$ & $(0.64)$ & $(0.66)$ & $(0.50)$ \\
\hline \multicolumn{5}{|c|}{ Benchmark Assets: NAREIT and NCREIF } \\
\hline 4.37 & 4.57 & 4.18 & 2.14 & 4.03 \\
\hline$(0.11)$ & $(0.1016)$ & $(0.12)$ & $(0.13)$ & $(0.13)$ \\
\hline
\end{tabular}
10.04
11.16
9.06
5.35
$(0.01)^{* * *}$

Benchmark

Europe

0.58

0.59

0.58

0.62

Assets: NCREIF

4.06

4.24

3.90

2.03

alized Europe
1.02
$(0.60)$
$(0.60)$
1.01
4.73
1.29
(0.63)
$(0.52)$

Benchmark

Panel C: Test assets: Orthogonalized European real estate securities

\begin{tabular}{|c|c|c|c|c|}
\hline $\begin{array}{l}40.50 \\
(0.00)^{* * *}\end{array}$ & $\begin{array}{l}63.61 \\
(0.00)^{* * *}\end{array}$ & $\begin{array}{l}27.36 \\
(0.00)^{* * *}\end{array}$ & $\begin{array}{l}30.48 \\
(0.00) * * *\end{array}$ & $\begin{array}{l}95.53 \\
(0.00)^{* * *}\end{array}$ \\
\hline \multicolumn{5}{|c|}{ Benchmark Assets: NAREIT and orthogonalized Asia } \\
\hline $\begin{array}{l}31.05 \\
(0.00)^{* * *}\end{array}$ & $\begin{array}{l}43.66 \\
(0.00)^{* * *}\end{array}$ & $\begin{array}{l}22.86 \\
(0.00)^{* * *}\end{array}$ & $\begin{array}{l}20.45 \\
(0.00)^{* * *}\end{array}$ & $\begin{array}{l}57.80 \\
(0.00)^{* * * *}\end{array}$ \\
\hline \multicolumn{5}{|c|}{ Benchmark Assets: NCREIF } \\
\hline 11.05 & 12.43 & 9.87 & 5.95 & 14.47 \\
\hline$(0.00)^{* * *}$ & $(0.00)^{* * *}$ & $(0.01)^{* * *}$ & $(0.01)^{* * *}$ & $(0.00)^{* * *}$ \\
\hline \multicolumn{5}{|c|}{ Benchmark Assets: NCREIF and orthogonalized Asia } \\
\hline 7.89 & 8.57 & 7.27 & 4.02 & 8.13 \\
\hline$(0.02)^{* *}$ & $(0.01)^{* * *}$ & $(0.03)^{* *}$ & $(0.02)^{* *}$ & $(0.02)^{* *}$ \\
\hline \multicolumn{5}{|c|}{ Benchmark Assets: NAREIT and NCREIF } \\
\hline 12.43 & 14.18 & 10.95 & 6.65 & 18.31 \\
\hline$(0.00)^{* * *}$ & $(0.00)^{* * *}$ & $(0.00)^{* * *}$ & $(0.00)^{* * *}$ & $(0.00)^{* * *}$ \\
\hline \multicolumn{5}{|c|}{ Benchmark Assets: NAREIT, NCREIF and orthogonalized Asia } \\
\hline 9.07 & 9.99 & 8.27 & 4.58 & 12.47 \\
\hline$(0.01)^{* * *}$ & $(0.01)^{* * *}$ & $(0.02)^{* *}$ & $(0.02)^{* *}$ & $(0.00) * * *$ \\
\hline
\end{tabular}


Table 12: Tests with orthogonalized returns for the period 1978:1-1998:1
$L R$
$W$
$L M$
$F$
$\boldsymbol{W a}$

Panel A: Test assets: Orthogonalized Asian and European real estate securities

\begin{tabular}{|c|c|c|c|c|}
\hline \multicolumn{5}{|c|}{ Benchmark Assets: NAREIT } \\
\hline $\begin{array}{l}94.75 \\
(0.00)^{* * *}\end{array}$ & $\begin{array}{l}179.83 \\
(0.00)^{* * *}\end{array}$ & $\begin{array}{l}55.89 \\
(0.00)^{* * *}\end{array}$ & $\begin{array}{l}31.00 \\
(0.00)^{* * *}\end{array}$ & $\begin{array}{l}8515.40 \\
(0.00)^{* * *}\end{array}$ \\
\hline \multicolumn{5}{|c|}{ Benchmark Assets: NCREIF } \\
\hline $\begin{array}{l}16.45 \\
(0.00) * * *\end{array}$ & $\begin{array}{l}18.21 \\
(0.00) * * *\end{array}$ & $\begin{array}{l}14.92 \\
(0.00)^{* * * *}\end{array}$ & $\begin{array}{l}4.17 \\
(0.00)^{* * *}\end{array}$ & $\begin{array}{l}361.90 \\
(0.00)^{* * *}\end{array}$ \\
\hline \multicolumn{5}{|c|}{ Benchmark Assets: NAREIT and NCREIF } \\
\hline $\begin{array}{l}15.59 \\
(0.00)^{* * *}\end{array}$ & $\begin{array}{l}17.18 \\
(0.00) * * *\end{array}$ & $\begin{array}{l}14.20 \\
(0.00)^{* * *}\end{array}$ & $\begin{array}{l}3.89 \\
(0.00)^{* * *}\end{array}$ & $\begin{array}{r}106.34 \\
(0.00)^{* * *}\end{array}$ \\
\hline \multicolumn{5}{|c|}{ Panel B: Test assets: Orthogonalized Asian real estate securities } \\
\hline \multicolumn{5}{|c|}{ Benchmark Assets: NAREIT } \\
\hline $\begin{array}{l}37.95 \\
(0.00)^{* * * *}\end{array}$ & $\begin{array}{l}48.41 \\
(0.00)^{* * * *}\end{array}$ & $\begin{array}{l}30.30 \\
(0.00)^{* * * *}\end{array}$ & $\begin{array}{l}23.61 \\
(0.00)^{* * * *}\end{array}$ & $\begin{array}{l}37.38 \\
(0.00)^{* * *}\end{array}$ \\
\hline \multicolumn{5}{|c|}{ Benchmark Assets: NAREIT and orthogonalized Europe } \\
\hline $\begin{array}{l}18.25 \\
(0.00) * * *\end{array}$ & $\begin{array}{l}20.47 \\
(0.00) * * *\end{array}$ & $\begin{array}{l}16.34 \\
(0.00)^{* * *}\end{array}$ & $\begin{array}{l}9.85 \\
(0.00) * * *\end{array}$ & $\begin{array}{l}21.08 \\
(0.00) * * *\end{array}$ \\
\hline \multicolumn{5}{|c|}{ Benchmark Assets: NCREIF } \\
\hline $\begin{array}{l}8.19 \\
(0.02)^{* *}\end{array}$ & $\begin{array}{l}8.61 \\
(0.01)^{* * *}\end{array}$ & $\begin{array}{l}7.79 \\
(0.02)^{* *}\end{array}$ & $\begin{array}{c}4.20 \\
(0.02)^{* *}\end{array}$ & $\begin{array}{l}7.29 \\
(0.03)^{* *}\end{array}$ \\
\hline \multicolumn{5}{|c|}{ Benchmark Assets: NCREIF and orthogonalized Europe } \\
\hline $\begin{array}{l}7.54 \\
(0.02)^{* * *}\end{array}$ & $\begin{array}{l}7.91 \\
(0.02)^{* * *}\end{array}$ & $\begin{array}{l}7.20 \\
(0.03)^{* * *}\end{array}$ & $\begin{array}{l}3.81 \\
(0.03) * * *\end{array}$ & $\begin{array}{l}7.36 \\
(0.03)^{* *}\end{array}$ \\
\hline \multicolumn{5}{|c|}{ Benchmark Assets: NAREIT and NCREIF } \\
\hline $\begin{array}{l}7.92 \\
(0.02)^{* * *}\end{array}$ & $\begin{array}{l}8.32 \\
(0.02)^{* * *}\end{array}$ & $\begin{array}{l}7.55 \\
(0.02)^{* * *}\end{array}$ & $\begin{array}{l}4.01 \\
(0.02) * * *\end{array}$ & $\begin{array}{l}6.80 \\
(0.03)^{* *}\end{array}$ \\
\hline
\end{tabular}

\begin{tabular}{|c|c|c|c|c|}
\hline \multicolumn{5}{|c|}{ Benchmark Assets: NAREIT, NCREIF and orthogonalized Europe } \\
\hline 7.31 & 7.65 & 6.99 & 3.64 & 6.92 \\
\hline$(0.03)^{* * *}$ & $(0.02)^{* * *}$ & $(0.03)^{* * *}$ & $(0.03)^{* * *}$ & $(0.03)^{* *}$ \\
\hline \multicolumn{5}{|c|}{ Panel C: Test assets: Orthogonalized European real estate securities } \\
\hline \multicolumn{5}{|c|}{ Benchmark Assets: NAREIT } \\
\hline 77.05 & 128.71 & 49.71 & 62.77 & 122.55 \\
\hline$(0.00) * * *$ & $(0.00) * * *$ & $(0.00)^{* * *}$ & $(0.00)^{* * *}$ & $(0.00)^{* * *}$ \\
\hline \multicolumn{5}{|c|}{ Benchmark Assets: NAREIT and orthogonalized Asia } \\
\hline 57.35 & 83.43 & 41.10 & 40.17 & 104.91 \\
\hline$(0.00) * * *$ & $(0.00) * * *$ & $(0.00) * * *$ & $(0.00)^{* * *}$ & $(0.00)^{* * *}$ \\
\hline \multicolumn{5}{|c|}{ Benchmark Assets: NCREIF } \\
\hline 12.32 & 13.30 & 11.42 & 6.49 & 11.23 \\
\hline$(0.00)^{* * *}$ & $(0.00)^{* * *}$ & $(0.00)^{* * *}$ & $(0.00)^{* * *}$ & $(0.00)^{* * *}$ \\
\hline \multicolumn{5}{|c|}{ Benchmark Assets: NCREIF and orthogonalized Asia } \\
\hline 11.67 & 12.56 & 10.87 & 6.05 & 10.87 \\
\hline$(0.00)^{* * *}$ & $(0.00)^{* * *}$ & $(0.00)^{* * *}$ & $(0.00)^{* * *}$ & $(0.00)^{* * *}$ \\
\hline \multicolumn{5}{|c|}{ Benchmark Assets: NAREIT and NCREIF } \\
\hline 12.32 & 13.31 & 11.43 & 6.41 & 11.08 \\
\hline$(0.00)^{* * *}$ & $(0.00)^{* * *}$ & $(0.00)^{* * *}$ & $(0.00)^{* * *}$ & $(0.00)^{* * *}$ \\
\hline \multicolumn{5}{|c|}{ Benchmark Assets: NAREIT, NCREIF and orthogonalized Asia } \\
\hline 11.71 & 12.60 & 10.90 & 5.99 & 10.71 \\
\hline$(0.00)^{* * *}$ & $(0.00) * * *$ & $(0.00) * * *$ & $(0.00)^{* * *}$ & $(0.00) * * *$ \\
\hline
\end{tabular}


Table 13: Tests with orthogonalized returns for the period 1998:2-2005:4
LR
$W$
$L M$
$F$
$\boldsymbol{W a}$

Panel A: Test assets: Orthogonalized Asian and European real estate securities

\begin{tabular}{|c|c|c|c|c|}
\hline \multicolumn{5}{|c|}{ Benchmark Assets: NAREIT } \\
\hline 21.44 & 30.54 & 15.66 & 5.78 & 2139.50 \\
\hline$(0.00) * * *$ & $(0.00) * * *$ & $(0.00)^{* *}$ & $(0.00)^{* * *}$ & $(0.00) * * *$ \\
\hline \multicolumn{5}{|c|}{ Benchmark Assets: NCREIF } \\
\hline 12.66 & 15.64 & 10.40 & 3.17 & 270.64 \\
\hline$(0.01)^{* * *}$ & $(0.00)^{* *}$ & $(0.03)^{* *}$ & $(0.02)^{* *}$ & $(0.00)^{* * *}$ \\
\hline \multicolumn{5}{|c|}{ Benchmark Assets: NAREIT and NCREIF } \\
\hline 10.23 & 12.12 & 8.72 & 2.42 & 78.54 \\
\hline$(0.04)^{* *}$ & $(0.02) * *$ & $(0.07)^{*}$ & $(0.06)^{*}$ & $(0.00)^{* * *}$ \\
\hline \multicolumn{5}{|c|}{ Panel B: Test assets: Orthogonalized Asian real estate securities } \\
\hline \multicolumn{5}{|c|}{ Benchmark Assets: NAREIT } \\
\hline 5.63 & 6.17 & 5.15 & 2.89 & 15.78 \\
\hline$(0.06)^{*}$ & $(0.05)^{* *}$ & $(0.08)^{*}$ & $(0.07)^{*}$ & $(0.00) * * *$ \\
\hline \multicolumn{5}{|c|}{ Benchmark Assets: NAREIT and orthogonalized Europe } \\
\hline 0.19 & 0.19 & 0.19 & 0.09 & 0.28 \\
\hline$(0.91)$ & $(0.91)$ & $(0.91)$ & $(0.92)$ & $(0.87)$ \\
\hline \multicolumn{5}{|c|}{ Benchmark Assets: NCREIF } \\
\hline 1.74 & 1.79 & 1.69 & 0.84 & 1.74 \\
\hline$(0.42)$ & $(0.41)$ & $(0.43)$ & $(0.44)$ & $(0.42)$ \\
\hline \multicolumn{5}{|c|}{ Benchmark Assets: NCREIF and orthogonalized Europe } \\
\hline 0.07 & 0.07 & 0.07 & 0.03 & 0.07 \\
\hline$(0.96)$ & $(0.96)$ & $(0.96)$ & $(0.97)$ & $(0.96)$ \\
\hline \multicolumn{5}{|c|}{ Benchmark Assets: NAREIT and NCREIF } \\
\hline 1.72 & 1.77 & 1.67 & 0.80 & 1.75 \\
\hline$(0.42)$ & $(0.41)$ & $(0.43)$ & $(0.46)$ & $(0.42)$ \\
\hline
\end{tabular}

Benchmark Assets: NAREIT, NCREIF and orthogonalized Europe
0.13
0.13
0.13
0.06
0.10
$(0.94)$
(0.94)
(0.94)
$(0.95)$
$(0.95)$

Panel C: Test assets: Orthogonalized European real estate securities

\begin{tabular}{lllll}
23.40 & \multicolumn{5}{c}{} & 16.34 & 62.83 \\
$(0.00)^{* * *}$ & 34.94 & 16.43 & $(0.00)^{* * *}$ & $(0.00)^{* * *}$
\end{tabular}

\begin{tabular}{|c|c|c|c|c|}
\hline \multicolumn{5}{|c|}{ Benchmark Assets: NAREIT and orthogonalized Asia } \\
\hline 17.96 & 24.32 & 13.63 & 10.99 & 36.94 \\
\hline$(0.00)^{* * *}$ & $(0.00)^{* * *}$ & $(0.00)^{* * *}$ & $(0.00)^{* * *}$ & $(0.00)^{* * *}$ \\
\hline \multicolumn{5}{|c|}{ Benchmark Assets: NCREIF } \\
\hline 7.59 & 8.59 & 6.73 & 4.02 & 11.21 \\
\hline$(0.02)^{* *}$ & $(0.01)^{* * *}$ & $(0.03)^{* *}$ & $(0.03)^{* *}$ & $(0.00)^{* * *}$ \\
\hline \multicolumn{5}{|c|}{ Benchmark Assets: NCREIF and orthogonalized Asia } \\
\hline 5.92 & 6.52 & 5.39 & 2.95 & 6.94 \\
\hline$(0.05)^{* *}$ & $(0.04)^{* *}$ & $(0.07)^{*}$ & $(0.07)^{*}$ & $(0.03)^{* *}$ \\
\hline \multicolumn{5}{|c|}{ Benchmark Assets: NAREIT and NCREIF } \\
\hline 8.04 & 9.18 & 7.09 & 4.15 & 17.35 \\
\hline$(0.02)^{* *}$ & $(0.01)^{* * *}$ & $(0.03)^{* *}$ & $(0.03)^{* *}$ & $(0.00) * * *$ \\
\hline \multicolumn{5}{|c|}{ Benchmark Assets: NAREIT, NCREIF and orthogonalized Asia } \\
\hline 6.45 & 7.017 & 5.83 & 3.12 & 11.08 \\
\hline$(0.04)^{* *}$ & $(0.03) * *$ & $(0.05)^{* *}$ & $(0.06)^{*}$ & $(0.00)^{* * *}$ \\
\hline
\end{tabular}




\section{CONCLUSIONS}

This study examines the diversification benefits of Asian and European real estate securities from the perspective of U.S. real estate investors. The spanning test results reveal that cross-continental real estate stocks do not always help enhance the meanvariance efficient frontier. The role of international real estate securities is sensitive to the specification of benchmark assets. Our test results show that including overseas real estate securities helps enhance the mean-variance efficient frontier of a real estate portfolio only when the portfolio does not include direct real estate assets. Furthermore, this diversification benefit of Asian real estate stocks appears only in the vintage REIT era; it disappears in the new REIT era and after the Asian financial crisis.

These results are consistent with Wilson and Zurbruegg (2002). The authors show that U.S. real estate securities have become more interrelated with international real estate securities since early 1990s. Our findings also support investors' suspicions about the benefit of Asian real estate investment after the Asian crisis (Mei, 1999).

Our results suggest that Asian real estate securities do not appear to have particularly unique return characters. Diversification into Asian real estate securities does not provide significant benefits to U.S. real estate investors who already hold European securities. Complementing Chiang and Lee (2006), our results show that Asian and European real estate securities lose their diversification effects when unsecuritized real estate is included into portfolio holdings.

Complementing Stevenson (2002) for the period 1980 to 1997, after stripping out the stock market influences, the test results indicates that cross-continental real estate investing provides significant diversification benefits even when U.S. investors already hold physical real estate in their domestic portfolios. Further analyses indicate that the diversification benefits after the structural breaks come primarily from European rather than Asian real estate investment. The results from orthogonalized data reveal that international real estate stocks are not always the same as overseas direct real estate investments. Trading noise in equity markets can cause real estate stocks to deviate from their real estate fundamentals and thus reduce the diversification benefits to U.S. real estate investors.

\section{REFERENCES}

Addae-Dappah, K. and Kion, C. (1996), International Diversification of Property Stock: A Singaporean investor's viewpoint, Real Estate Finance, 13(3), 54-66.

Asabere, P.K., Kleiman, R.T. and McGowan, C.B. (1991), The Risk Return Attributes of International Real Estate Equities, Journal of Real Estate Research, 62(2), 143-151. 
Bigman, T. (2002), Investing in International Listed Property Companies, PREA Quarterly, Winter, 53-61.

Bigman, T. and Chiu, C. (2005), The Case for a Strategic Allocation to Global Real Estate Securities, Morgan Stanley Investment Management Journal, 1(2), 15-34.

Books, C. and Tsolacos, S. (1999), The Impact of Economic and Financial Factors on UK Property Performance, Journal of Property Research, 16, 139-152.

Chan, S.H., Leung, W.-K. and Wang, K. (2005), Changes in REIT Structure and Stock Performance: Evidence from the Monday Stock Anomaly, Real Estate Economics, 33(1), 89-120.

Chiang, K.C.H. and Lee, M-L. (2007), Spanning Tests on Public and Private Real Estate, Journal of Real Estate Portfolio Management, 13, 7-16.

Clayton, Jim and Mackinnon, Greg.(2003), The Relative Importance of Stock, Bond, and Real Estate Factors in Explaining REIT Returns, Journal of Real Estate Finance and Economics, 27, 39-60.

Crain, J.L., Cudd, M. and Brown, C.L. (2000), The Impact of the Revenue Reconciliation Act of 1993 on the Pricing Structure of Equity REITs, Journal of Real Estate Research, 19(3), 275-285.

Eichholtz, P. (1997), How to Invest Internationally: Region and Property Type on a Global Scale, Real Estate Finance, 14(3) 70-74.

Eichholtz, P. Mahieu, R. and Schotman, P. (1993), Real Estate Diversification: By Country or by Continent? Working paper, Limburg University, Maastricht.

Eichholtz, P.M.A. (1996), Does International Diversification Work Better for Real Estate than for Stocks and Bonds, Financial Analysts Journal, January-February, 56-62.

Ferson, W., Foerster, S.R., and Keim, D.B. (1993), General Tests of Latent Variable Models and Mean-Variance Spanning, Journal of Finance, 48, 131-156.

Gilberto, S. (1990), Global Real Estate Securities: Index Performance and Diversification Portfolios, Salomon Brothers, Inc.

Glascock, J.L., Lu, C. and So, R.W. (2000), Further Evidence on the Integration of REIT, Bond, and Stock Returns, Journal of Real Estate Finance and Economics, 20, 177-194. 
Hamelink, F. and Hoesli, M. (2004), What Factors Determine International Real Estate Securities Returns? Real Estate Economics, 32, 437-467.

Hansen, L.P. (1982), Large Sample Properties of the Generalized Method of Moments Estimators, Econometrica, 50, 1029-1054.

He, L.T. (2002), Excess Returns of Industrial Stocks and the Real Estate Factor, Southern Economic Journal, 68, 632-645.

Huberman, G., and Kandel, S. (1987), Mean-Variance Spanning, Journal of Finance, 42, 873-888.

Kan, R., and Zhou, G. (2001) Test of Mean-Variance Spanning, Working Paper, University of Toronto.

Lee, M-L., Lee, M-T., and Chiang, K.C.H. (2007), Real Estate Risk Exposure of Equity Real Estate Investment Trusts, Journal of Real Estate Finance and Economics, forthcoming.

Lee. M-L., and Lee, M-T. (2003), Institutional Involvement and the REIT January Effect Over Time, Journal of Property Investment and Finance, 21, 435-449.

Liow, K.H. and Sim, M.C. (2006), The Risk and Return Profile of Asian Real Estate Stocks, Pacific Rim Property Research Journal, 12, 283-310.

Liu, C. and Mei, J-P. (1996), The Predictability of International Real State Markets, Exchange Rate Risks and Diversification consequences, Real Estate Economics, 26(1), 339.

McCue, T.E. and Kling, J.L. (1994), Real Estate Returns and Macroeconomics: Some Evidence from Real Estate Investment Trust Data, 1972-1991, Journal of Real Estate Research, 9, 277-289.

Mei, J-P. (1999), Asian Real Estate in a Portfolio Context: Long-Term Opportunities, Real Estate Finance, 15, 85-94.

Mull, S.R. and Soenen, L.A. (1997), REITs as an Asset Class in International Investment Portfolios, Financial Analysts Journal, 53, 55-61.

Pierzak, E. (2001) Exploring International Property Securities for US Investors, Henderson Global Investors Property Economics \& Research. 
Sing, Tien F., Ho, K.H.D., and Mark, Mei F. (2002), Real Estate Market Reaction to Public Listings and Acquisition News of Malaysian REITs, Journal of Real Estate Portfolio Management, 8(3), 209-227.

Stevenson, S. (2000), International Real Estate Diversification: Empirical Tests using Hedged Indices, Journal of Real Estate Research, 19, 105-131.

Stevenson, S. (2001), A Re-Examination of the Inflation-Hedging Ability of Real Estate Securities: Empirical Tests Using International Orthogonalized \& Hedged Data, International Real Estate Review, 4, 26-42.

Stevenson, S. (2003), International Real Estate Security Diversification: Empirical Evidence using Mean-Variance Spanning Tests, Paper presented at PRRES conference, Brisbane, Australia.

Torto, R.G. (2002), Benefits and Issues in Global Real Estate Investing: a Review of the Research, Real Estate Issues, 27, 38-40.

Tuluca, S.A., Myer, F.C.N.and Webb, J.R. (2000), Dynamics of Private and Public Real Estate Markets, Journal of Real Estate Finance and Economics, 21, 279-296.

Wilson, P.J. and Okunev, J. (1996), Evidence of Segmentation in Domestic and International Property Markets, Journal of Property Finance, 7(4), 42-59.

Wilson, P.J. and Zurbruegg, R. (2002), Structural Breaks, Diversification and International Real Estate Markets - Some New Evidence, Briefings in Real Estate Finance, 1(4), 348-366.

Wilson, P.J. and Zurbruegg, R. (2003), International Diversification of Real Estate Assets: Is it

Worth it? Evidence from the literature, Journal of Real Estate Literature, 11(3), 259-277.

Worzala, E. and Sirmans, C.F. (2003), Investing in International Real Estate Stocks: A Review of the Literature, Urban Studies, 50(5-6), 1115-1149.

Ziering, B., Winograd, B. and McIntosh, W (1997), The Evolution of Public and Private Market Investing in the New Real Estate Capital Markets, Parsippany, NJ: Prudential Real Estate Investors, 1997. 